\title{
Starfish-Type Glycoclusters: Molecular Design for High-Affinity Carbohydrate Ligand to Bind to Toxins
}

\section{ヒトデ型糖クラスター：毒素に対する高親和性糖鎖リガンドの分子設計}

Key Words : glycocluster, heat-labile enterotoxin, molecular design, Shiga-like toxin, starfish ligand

It has been known that most carbohydrates in the living system express stronger molecular recognition ability as a molecular assembly than as a single molecule. This has been called the multivalent or cluster effect, and has become a principle in the design of artificial glycoconjugate ligands. It has been considered that the multivalent or cluster effect on the carbohydraterelated recognition is caused by favorable enthalpy change based on multiple binding and entropic gain due to preorganization of a carbohydrate unit. Thus, if we design a carbohydrate ligand that has a shape adaptable to the geometry of the binding site on the target carbohydrate-binding protein, we may develop a carbohydrate ligand with high affinity to the specific receptor due to the entropic gain.

Carbohydrate-binding toxins such as Shiga, Shiga-like (Vero), heat-labile entero-, pertussis and cholera toxins have an $\mathrm{AB}_{5}$ subunit structure. The $\mathrm{B}$ subunit forms a doughnut-shaped pentamer with saccharide-binding sites aligned on one face of the toxins, which recognize a glycolipid cluster on the cell surface. One strategy for the design of viable medicine against these toxins is inhibition of adhesion of the toxins on the cell surface by carbohydrate derivatives. Therefore, it is expected that an artificial carbohydrate ligand which has a shape adaptable to the geometry of the binding site on the $B$ subunit pentamer of the toxins will effectively inhibit adhesion of the toxins.

Recently, artificial carbohydrate ligands to the toxins based on the molecular design described above were reported by two independent groups at almost the same time. They showed that the glycocluster ligands which have a starfish-like shape bind to the pentagonal B subunits of the toxins with high affinity. P. I. Kitov et al. developed the starfish-type glycocluster ligand which very strongly $\left(K_{\mathrm{d}} \sim 10^{-9} \mathrm{M}\right)$ bind to Shiga-like toxins, SLT-I and SLT-II [P. I. Kitov et al., Nature, 403, 669-672 (2000)]. This is a decavalent glycocluster ligand consisting of a glucose core, five flexible linkers, and ten $\mathrm{Gb} 3$ oligosaccharides tethered at the tips of each linker. Since X-ray crystallography of the SLTs showed that the spacing from the center of the pentameric B subunits to a $\mathrm{Gb} 3$ binding site is about $\sim 30 \AA$, the linker of the glycocluster ligand was designed to be $\sim 30 \AA$ to fit the geometry. The in vitro inhibitory activity of the tailored multivalent ligand was $10^{6}-10^{7}$-fold higher than that of a monovalent ligand and was the highest molar activity of any inhibitor yet reported for SLT-I and II.
生体内において糖鎖の多くは、単独よりも集合化すること で、より強い分子認識能を発現することが知られている。この ようなものは、多価効果あるいはクラスター効果と呼ばれ、人 工糖鎖リガンドの分子設計の指針となっている。糖鎖の関与す る分子認識における多価あるいはクラスター効果は、多点結合 によるエンタルピー的有利さと、糖鎖の事前組織化によるエン トロピー的利得が要因であると考えられている。それゆえ、も し、標的の糖鎖結合性タンパク質の結合部位の幾何学的配置に 適合しうる形状をもつ糖鎖リガンドを分子設計すれば、エント ロピー的利得により、高親和性の糖鎖りガンドを開発できる。

志賀毒素、志賀様毒素(ベロ毒素)、易熱性腸毒素、百日咳お よびコレラ毒素のような糖鎖認識性毒素は、いずれも $\mathrm{AB}_{5}$ サブユ ニット構造を持っている。B サブユニットは、毒素の片面に糖 結合部位を配したドーナツ状の五量体を形成しており、これが 細胞膜表面の糖脂質クラスターを認識する。これらの毒素に対 する効果的な医薬品設計の戦略の一つは、毒素の細胞膜への付 着を糖誘導体により阻害することである。従って、毒素のBサブ ユニット五量体上の糖結合部位の配置に適合しうる形状をもつ 人工糖鎖りガンドは、効果的に毒素の付着を阻害することが期 待できる。

最近、上で述べたような分子設計に基づいた毒素に対する 人工糖鎖リガンドが、二つの独立した研究グループによりほと んど同時期に報告されている。彼らは、ヒトデのような形状の 糖クラスターが、五角形状の毒素 B サブユニットに対して高い 親和性で結合することを示した。P. I. Kitov らは、志賀様毒素 SLT-I およびSLT-II に対して非常に強く $\left(K_{\mathrm{d}} \sim 10^{-9} \mathrm{M}\right)$ 結合する ヒトデ型糖クラスターリガンドを開発した[P. I. Kitov et al., Nature, 403, 669-672 (2000)]。これは、グルコースの核、五本の柔 軟なリンカー、それぞれの先端に繋げた $\mathrm{Gb} 3$ 糖鎖 10 個から成る 10 価の糖クラスターリガンドである。SLT の B サブユニット 五量体の中心から結合部位までの距離は、約 $30 \AA$ であることが $\mathrm{X}$ 線結晶構造解析からわかっているので、この糖クラスターリ ガンドのリンカーは、その幾何構造に合致するために約 $30 \AA$ なるように設計されている。in vitroでのこの仕立てられた多価 リガンドの阻害活性は、一価のリガンドに比べ 1000 万倍の阻害 活性であり、これまで報告されたなかで最も活性の高い阻害剤 であった。 
On the other hand, E. Fan et al. reported that a starfishtype carbohydrate ligand consisting of a pentacyclen core and five $\mathrm{N}$-galactosides tethered by linkers at the tips strongly binds to Escherichia coli heat-labile enterotoxin [E. Fan et al., J. Am. Chem. Soc., 122, 2663-2664 (2000)]. The average spacing between two N-galactosides was controlled by the length of the linker. The ligand which adapted to the dimensions of the binding site distribution in the toxin exhibited the best affinity to the toxin $\left(\mathrm{IC}_{50}=0.56 \mu \mathrm{M}\right)$. This affinity corresponded to $10^{5}$-fold gain over that of galactose and was comparable to natural ligand GM1 oligosaccharide.

In summary, it has been shown that the starfish-type carbohydrate ligands, designed to adapt to the geometry of $\mathrm{AB}_{5}$ toxins, bind to the toxins with very high affinity. Although numerous glycoconjugate polymers and dendrimers have been synthesized as an artificial glycocluster, these were designed without consideration to the geometry of the receptors and were merely crowded with carbohydrate residues. As the paper introduced here describes, precise molecular design of a carbohydrate ligand which controls the arrangement and geometry between the carbohydrate residues will become increasingly important in glycobiology and glycotechnology.

\section{Reported by Kazunori Matsuura}

Department of Molecular Design, Graduate School of Engineering, Nagoya University Furou-cho, Chikusa-ku, Nagoya, 464-8603, Japan

FAX: 81-52-789-2528
一方、E. Fan らは、ペンタサイクレンの核と先端に五個の N-ガラクトシドから成るヒトデ型糖リガンドが、大腸菌易熱性 腸毒素に対して強く結合することを報告した[E. Fan et al., J. Am. Chem. Soc., 122, 2663-2664 (2000)]。二つのN-ガラクトシド間の 平均距離はスペーサーの長さを変えることで調節された。毒素 の結合部位分布の大きさと適合するリガンドが、毒素に対して 最大の結合活性を示した $\left(\mathrm{IC}_{50}=0.56 \mu \mathrm{M}\right)$ 。これは、ガラクトー ス単独の場合の約 $10^{5}$ 倍の活性に相当し、天然リガンドの GM1 の值に匹敵するものであった。

以上のように、 $\mathrm{AB}_{5}$ 型毒素の構造に適応するように分子設 計されたヒトデ型糖リガンドは、非常に高い親和性で毒素に結 合することが示された。これまで、人工糖クラスター分子とし て、多くの糖鎖高分子や糖デンドリマーなどが合成されてきて いるが、これらは糖レセプターの形状を考慮して設計されてい るわけではなく、単に糖鎖が密集しているにすぎない。ここで 紹介した論文のように、糖鎖間の配置と幾何構造を制御した糖 鎖リガンドの精密な分子設計は、今後、糖鎖生物学および糖鎖 工学においてますます重要になってくると思われる。

名古屋大学大学院 $\cdot$ 工学研究科・物質制御工学 松浦 和則 